\title{
MYOSTATIN GENE SEQUENCING AND ITS ASSOCIATION WITH GROWTH PERFORMANCE OF MAGHRABI CAMEL BREED
}

\author{
Ismail, M. Ismail $^{1 *}$, Mohamed M. Mourad ${ }^{2}$, Mohamed A. Rashed ${ }^{3}$ \\ and Ibrahim S. Ramadan ${ }^{1}$ \\ ${ }^{1}$ Animal and Poultry Breeding Department, Desert Research Center, \\ El-Matareya, Cairo, Egypt \\ ${ }^{2}$ Animal Production Department, Faculty of Agriculture, Ain Shams \\ University, Cairo, Egypt \\ ${ }^{3}$ Genetics Department, Faculty of Agriculture, Ain Shams University, \\ Cairo, Egypt \\ *E-mail: ssmm_ismail@yahoo.com
}

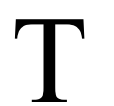

wenty-three (11 dams and 12 of their offspring; 7 males and 5 females) Maghrabi camels (Camelus dromedaries) belonging to Camel Research Station, Matrouh, Agricultural Research Center, Ministry of Agriculture, Egypt were used to study growth performances (birth BW, weaning WW, yearling YW weights, average daily gain from birth to weaning ADG1 and average daily gain from weaning to yearling ADG2) and to identify the myostatin gene in the second exon polymorphism. The sequence of the myostatin gene was done using heterologous oligonucleotide primers designed from the publicly available sequence of the myostatin gene (NCBI GenBank). Results showed that the average BW (28.9 and $26.3 \mathrm{~kg})$, WW (99.6 and $77 \mathrm{~kg}$ ), YW (152.3 and $116.5 \mathrm{~kg}$ ), ADG1 (392.7 and $281.5 \mathrm{~g}$ /day) and ADG2 (342.6 and $250.4 \mathrm{~g} /$ day) for males and females, respectively. While, phenotypic correlation coefficients between weaning and yearling weights were positive and highly significant $(p<0.01)$ with an estimate of 0.973 . Results of this study showed no polymorphism in the $230 \mathrm{bp}$ region of the second exon of the myostatin gene. Thus, there was no relation between myostatin gene sequence and growth performance of Maghrabi camels. Therefore, a complete sequence of the myostatin gene and its relationship with muscle hypertrophy mechanism are needed to be used in genetic improvement programs in Maghrabi camels.

Keywords: myostatin sequencing, growth performance, Maghrabi camel 
Camel productivity is low due to the weak calving, which is lower than $45 \%$, per female per year, also the high rate of calving loss, which mainly occurs during dry seasons. Growth rate of young camels are determined by sex, genetic potentiality and mainly affected by nutrition and health status of the animals (Bakheit et al., 2017). The growth rate varies according to the availability of food and may be altered seasonally; especially in the outdoor feeding camel, which is a popular husbandry regime.

Myostatin, or growth differentiation factor-8 (GDF-8), is a member of the mammalian growth transforming family (TGF-beta super family), which is expressed specifically in developing the muscles of the posterior part of the animal (particularly the femur muscles) as shown in many breeds of cattle and sheep. Gonzalez-Cadavid and Bhasin (2004) and Jeanplong et al. (2001) found that molecular analysis showed that this gene consists of three exons and two introns, with 373, 374 and 381 nucleotides in each exon, and 1840 and 2033 nucleotides in each intron. McPherron and Lee (1997) found that alignment of the myostatin gene sequence from several vertebrates (baboons, bovines, chickens, humans, mice, ovine, porcine, rats, turkeys and zebra fish) has showed a high degree of conservation among species. Variation in the GDF8 gene was first discovered in mice by McPherron and Lee (1997), then identified in cattle by Grobet et al. (1997 and 1998), who had explained large muscle phenotypic differences among several breeds. Moreover, Grobet et al. (1997) and Kambadur et al. (1997) investigated the GDF8 gene extensively in bovines and identified a large number of alleles. Several mutations in both the second and third exons strongly affected the phenotype were described by Grobet et al. (1998) as responsible for muscle hypertrophy (double-muscled) and for increased meat production in several breeds.

Therefore, the objective of this study was to describe some patterns of growth and to determine genetic polymorphism of the myostatin gene and its relationship with growth performance of Maghrabi camel breed.

\section{MATERIALS AND METHODS}

\section{Animals}

Twenty-three Maghrabi camels (11 she-camels and 12 of their offspring; 7 males, 5 females) were obtained from Camels Research Station, Matrouh, Agricultural Research Center, Ministry of Agriculture and Land Reclamation, Egypt. Camels were kept under a semi intensive production system and were housed in open yards and newborns were left twice daily with dams for suckling to the weaning age at six months. The duration of the experiment was about 12 months. She-camels were daily fed on a feed concentrate $(3.5 \mathrm{~kg})$, rice straw $(2 \mathrm{~kg})$ and berseem hay $(2.5 \mathrm{~kg})$ per head in summer, but in winter berseem hay was replaced by $15 \mathrm{~kg}$ of fresh berseem 
and camel calves were fed only on $50 \%$ of their dams milk (about $3 \mathrm{~kg}$ of milk) from birth to weaning at six months of age. After weaning, calves were fed on $1.5 \mathrm{~kg}$ feed concentrate and $1 \mathrm{~kg}$ berseem hay until the yearling age. Fresh water was available to camels all day long.

\section{Growth Performance Data}

Birth, weaning (6 months age) and yearling (12 months age) weights data were recorded for each camel by electronic balance. Average daily gain (ADG1) from birth up to weaning and ADG2 from weaning up to yearling were calculated.

\section{PCR Amplification and Sequence Analysis}

Blood samples of the twenty-three Maghrabi camels were taken in this study. DNA was extracted from the blood samples using commercially available (ReliaPrep ${ }^{\mathrm{TM}}$ Blood gDNA Miniprep System kit, Promega Corporation, Madison, USA) kit, according to manufacturer's instructions.

Myostatin primer pairs were designed based on the published nucleotide sequence information of the Myostatin gene (NCBI GenBank). The primer sequences are shown in table (1).

Table (1). Primer sequences and PCR protocol.

\begin{tabular}{cll}
\hline & \multicolumn{1}{c}{ Primer sequences } & \multicolumn{1}{c}{ PCR protocol } \\
\hline Myostatin & for $\left(5^{\prime} C G C\right.$ TCC GGG AAC TGA TTG A 3') & initial denaturation at $94^{\circ} \mathrm{C}$ \\
gene & $\operatorname{rev}\left(5^{\prime} \mathrm{TGG}\right.$ GAA GGT TAC AGC AAG AT3') & for 2 min, 35 cycles were \\
& & done, each consisting of \\
& & $94^{\circ} \mathrm{C}$ for 1 min, $60^{\circ} \mathrm{C}$ for 30 \\
& $\mathrm{~s}$ and $72^{\circ} \mathrm{C}$ for $40 \mathrm{~s}$. The \\
& final step lasted for 10 min \\
& at $72^{\circ} \mathrm{C}$. \\
\hline
\end{tabular}

PCR reactions were carried out in a total volume of $25 \mu l$ containing $3 \mu \mathrm{l}$ of genomic DNA, $12.5 \mu \mathrm{l}$ of GO Taq Green Master Mix, $1 \mu \mathrm{l}$ of forward primer, $1 \mu \mathrm{l}$ of reverse primer and $7.5 \mu \mathrm{l}$ of nuclease-free water. The amplified DNA fragments were separated by $1.5 \%(\mathrm{w} / \mathrm{v})$ agarose gel electrophoresis on a constant power $(I=120)$ for 1 hour. Samples were loaded with Fermentas ${ }^{\mathrm{TM}} 100 \mathrm{bp}$ DNA ladder and reveled using a pre-added staining solution $1 \mathrm{X}$ ethidium bromide under UV trans-illuminator. The visualized bands were documented by the gel documentation system SYNGENE UK. Amplified fragments were cleaned and concentrated using Fermentas (GeneJET PCR Purification Kit \#K0702) according to manufacturer's instructions. Cleaned fragments were sequenced by sequencing service (Macrogen, Netherlands). The obtained sequences were analysed using Basic Local Aligned Tool (BLAST) online on the National

Egyptian J. Desert Res., 67, No. 1, 117-126 (2017) 
Center for Biotechnology Information (NCBI) to determine the Single Nucleotide Polymorphism (SNP).

\section{Statistical Analysis}

Growth performance data were statistically analyzed and simple correlation coefficients among birth weight, weaning weight and yearling weight were calculated and tested for significance according to SPSS (2012). Sequences were analyzed using BIO EDIT V3 program.

\section{RESULTS AND DISCUSSION}

\section{Growth Performance Traits}

The averages and standard errors of live body weights are shown in table (2). The average of birth BW for males and females were 28.9 and 26.3 $\mathrm{kg}$, respectively. Birth weight varied widely between regions, breeds and for instance, reports of birth weights include 26-28 kg for Somali camels (Field, 1979 and Ouda, 1995); $27 \mathrm{~kg}$ for Tunisian camels (Hammadi et al., 2001) and $39 \mathrm{~kg}$ for Indian camels (Bissa, 1996). These differences in birth weight of camel calves may be attributed to the breed differences and production system among camel herds and their nutritional status.

Table (2). Average live bodyweights $(\mathrm{kg})$ and average daily gains $(\mathrm{g})$ of Maghrabi camel breed \pm stander errors.

\begin{tabular}{lcc}
\hline & Male & Female \\
\hline No. of animal & 7.0 & 5.0 \\
BW & $28.9 \pm 1.5$ & $26.3 \pm 1.9$ \\
WW & $99.6 \pm 8.2$ & $77.0 \pm 5.7$ \\
YW & $152.3 \pm 10.4^{*}$ & $116.5 \pm 6.1$ \\
ADG1 (BW-WW) & $392.7 \pm 55.4$ & $281.5 \pm 49.2$ \\
ADG2 (BW-YW) & $342.6 \pm 36.9$ & $250.4 \pm 32.3$ \\
\hline
\end{tabular}

BW, Birth Weight; WW, Weaning Weight; YW, Yearling Weight; ADG, Average Daily Gain

*Significant at $p \leq 0.05$

The average weaning weights (WW) at six months of age of camels were 99.6 and 77 for males and females, respectively. Also, the average of yearling weights (YW) of young camels were 152.3 and $116.5 \mathrm{~kg}$ for males and females, respectively. Therefore, the results in the present study showed much lower weaning and yearling weights than those reported by Sahani et al. (1998), who found that the weaning weight of camel ranged from 141.0 to $153.1 \mathrm{~kg}$ and the yearling weight of camels were 206.5, 199.3 and 203.3 $\mathrm{kg}$, in Bikaneri, Jaisalmeri and Kachchhi camel breeds, respectively. These differences in weaning and yearling weights may be due to several factors 
such as camel breed, production system, nutritional status and milk production of she-camels.

The obtained results indicated that the average daily gain (ADG1) of young camels from birth to weaning were 392.7 and $281.5 \mathrm{~g}$ /day in males and females, respectively. These results are in disagreement with those of Gitao (2006), who reported $250 \mathrm{~g} / \mathrm{day}$ as ADG1 for males in the same period. As well as Bakheit et al. (2009), who reported an average from 352 to $477 \mathrm{~g}$, daily. However, Kamoun (1995) found that average daily gain were 760 and $620 \mathrm{~g} /$ day for male and female camels between birth and weaning being higher than the estimated values. The breed as a factor was responsible with the greatest part of variation of live body weight and daily gain between birth and weight of calves.

The average daily gain (ADG2) from birth to yearling age was 342.6 and $250.4 \mathrm{~g} /$ day in males and females, respectively. Estimates of Guerouali and Acharbane (2004) were not far from the estimated values being 320 and $410 \mathrm{~g} /$ day in Marmouri and Guerzni camel breeds. Similar results were obtained by Dong (1979), Degen et al. (1987), Ismail (1996), Iqbal et al. (1999), Gitao (2006) and Bakheit et al. (2009). The growth rate varies according to the availability of food and may be altered seasonally; especially in the outdoor feeding camel, which is a popular husbandry regime (Bakheit et al., 2017). Breed and nutrition as factors play an important part in the variation of growth between birth and yearling age.

Simple phenotypic correlation coefficients between different weights of young camels are shown in table (3). The results indicated that correlation coefficients between birth weight and each of weaning and yearling weights were 0.523 and 0.511 , respectively (positively and nonsignificant). However, weaning weight was highly significantly $(p<0.01)$ correlated with yearling weight with an estimate of 0.973 .

Table (3). Correlation coefficients among birth, weaning and yearling weights of Maghrabi camels breed.

\begin{tabular}{lccc}
\hline Variables & BW & WW & YW \\
\hline BW & 1.000 & & \\
WW & 0.523 & 1.000 & \\
YW & 0.511 & $0.973^{*}$ & 1.000 \\
\hline
\end{tabular}

BW, Birth Weight; WW, Weaning Weight; YW, Yearling Weight,* Significant at $p \leq 0.01$

\section{Myostatin Gene Sequencing}

The obtained sequence of the myostatin gene in the second exon from Maghrabi camel breed was done using heterologous oligonucleotide primers, designed from the publicly available sequence of the myostatin gene. It was identified in many cattle breeds; such as Charolais and Lymosin and in many sheep breeds as Charolais, in dominant homozygous and

Egyptian J. Desert Res., 67, No. 1, 117-126 (2017) 
heterozygous genotypes, but the recessive allele expresses an ordinary animal. The sequences of this gene in camels were published in the NCBI GenBank. Jeanplong et al. (2001), Liangyi et al. (2006) and Ko et al. (2007) indicated that in all vertebrate, whose genomic sequences are publicly available, myostatin gene had three exons and two introns: exon 1 (379 bp), exon 2 (371 bp) and exon 3 (381 bp); intron 1 (363 bp) and intron 2 (811 bp). The obtained sequence of the myostatin gene is shown in fig. (1).

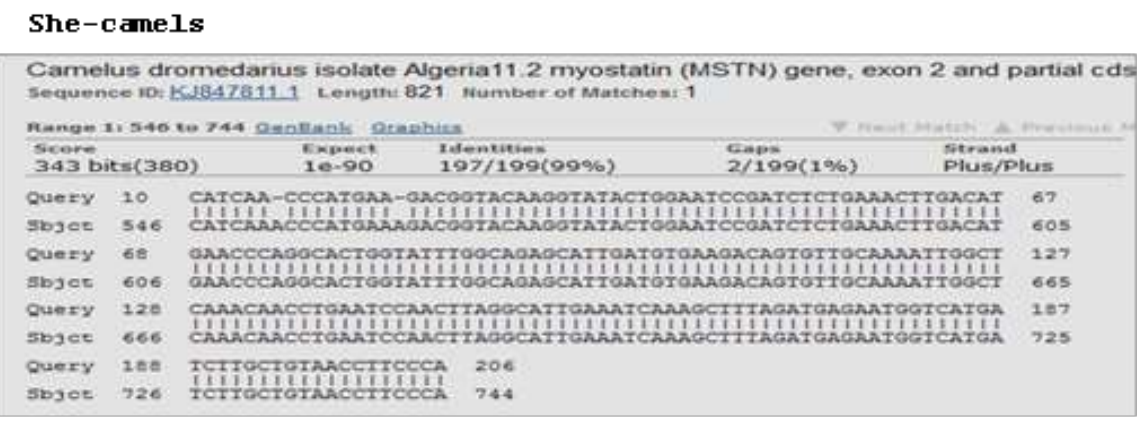

\section{offspring}

$$
\text { a. Males }
$$

Camelus dromedarius isolate A myostatin (MSTN) gene, exon 2 and partial cds sequence ID: KX R6.63740.1 Length: 375 number or Matches: 1

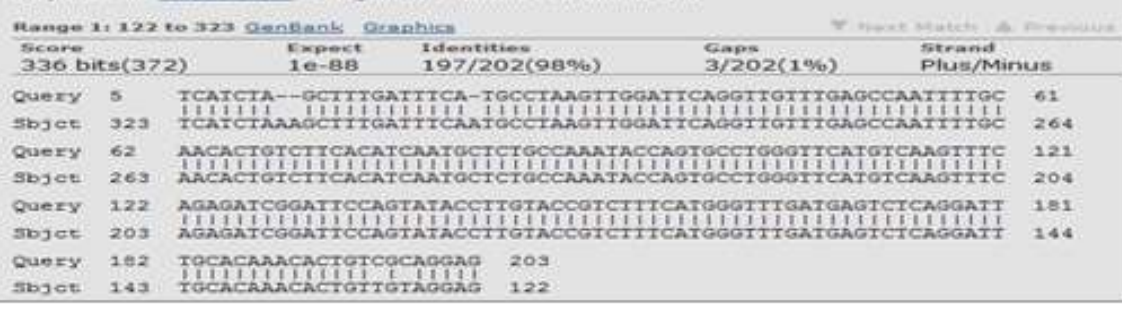

\section{b. Females}

Camelus dromedarius isolate A myostatin (MSTN) gene, exon 2 and partial cds

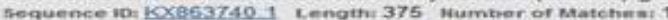

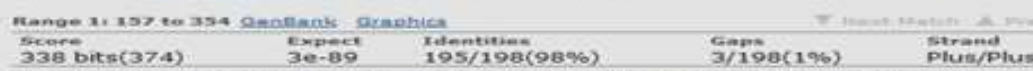

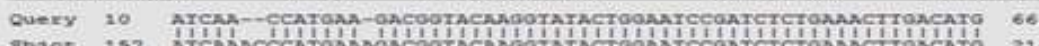

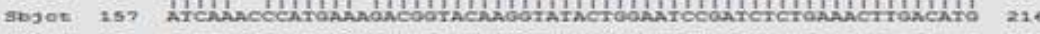

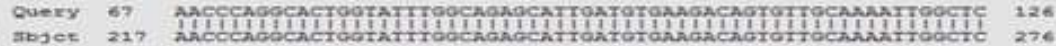

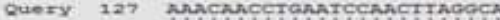

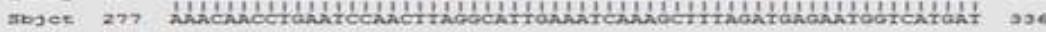
Query 187 CrTocroraAcerrecCA 204

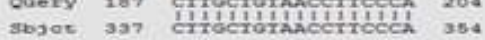

Fig. (1). Sequencing of myostatin gene; a part of exon 2 in she-camels, a. males and $\mathbf{b}$. females of Maghrabi camel breed.

No polymorphism in a $230 \mathrm{bp}$ region of the second exon of the myostatin gene was observed, so there is no correlation between its genotypes and live body weights and daily gain. Similar results were 
obtained by Shah et al. (2006), who screened a 256 bp region in the first exon of the Camelus dromedaries myostatin gene in 12 samples from six different Pakistani breeds without observing any sequence polymorphism. However, more than $90 \%$ homology of camel myostatin with that of the cattle, sheep and pig sequences published in the NCBI GenBank was found. In this trend, Muzzachi et al. (2015) did not observe any polymorphism in the second exon of the myostatin gene, but they detected three variant nucleotide sites located in the first intron in Camelus dromedaries. On the other hand, myostatin gene has more functional mutations in other species; such as cattle (Kambadur et al., 1997) and horse (Baron et al., 2012). Low level of genetic variation of camel myostatin gene may reflect the evolutionary history of camels compared to other livestock species. This has derived from the limited geographical distribution of the wild ancestor on the Arabian Peninsula and to the brief co-existence of wild and early domesticated individuals.

\section{CONCLUSION}

The study showed significant correlation coefficients (0.973) between WW and YW. Moreover, sequences of the myostatin gene in the exon 2 for Maghrabi camels in this study showed no polymorphism. Thus, there was no ability to find association between Myostatin gene sequence and growth performance of Maghrabi camels. Therefore, it is recommended to make a complete sequence of the Myostatin gene and to study its relationship with muscle hypertrophy mechanism to be used in genetic improvement programs in camels.

\section{REFERENCES}

Bakheit, S.A., B. Faye, I.E. Ibrahim and A.O. Idris (2017). Effect of management system on young camels growth rate and daily gain. Direct Res. J., 2 (1): 8-13.

Bakheit, S.A., B. Faye, A.M. Nikheila and A.M. Majid (2009).The impact of farming system on Sudanese young camels growth rate. The $2^{\text {nd }}$ Conference of the International Society of Camel Research and Development. Djerba, Tunisia, 12-14 March, 81 pp.

Baron, E.E., M.S. Lopes, D. Mendonça and A. da Câmara Machado (2012). SNP identification and polymorphism analysis in exon 2 of the horse myostatin gene. Anim. Genet., 43 (2): 229-232.

Bissa, U.J. (1996). Early growth and its association with certain blood parameters in different breeds of camel. M.Sc. Thesis, Department of Animal Breeding and Genetics. College of Veterinary and Animal Science, Rajasthan Agricultural University, Bikaner Camel Newsletter, 12: 21-23.

Egyptian J. Desert Res., 67, No. 1, 117-126 (2017) 
Degen, A.A., E. Elias and M. Kam (1987). A preliminary report on the energy intake and growth rate of early weaned camel (Camelus dromedariusi) calves. Anim. Prod., 45: 301.

Dong, W.E.I. (1979). Chinese camels and their productivities. Proceedings of Workshop on Camels, Khartoum, Sudan, 18-20 December, 55.

Field, C.R. (1979). Camel growth and milk production in Marsabit District, North Kenya, Preliminary report. Workshop on camel, Khartoum, Sudan, 18-20 December, p. 215-240.

Gitao, G.C. (2006). In "Camel Husbandry: A Practical Guide to Camel Husbandry". Downtown Printing Works Ltd., Nairobi, Kenya.

Gonzalez-Cadavid, N.F. and S. Bhasin (2004). Role of myostatin in metabolism. Curr. Opin. Clin. Nutr. Metab. Care, 7: 451-457.

Grobet, L., L.J.R. Martin, D. Poncelet, D. Pirottin, B. Brouwers and J. Riquet (1997). A deletion in the bovine myostatin gene causes the double-muscled phenotype in cattle. Nature Genetics, 17: 71-74.

Grobet, L., D. Poncelet, L.J. Royo, B. Brouwers, D. Pirottin, C. Michaux, F. Me'nnissier, M. Zanotti, S. Dunner and M. Georges (1998). Molecular definition of an allelic series of mutations disrupting the myostatin function and causing double-muscling in cattle. Mamm. Genome, 9: 210-213.

Guerouali, A. and R. Acharbane (2004). Camel genetic resources in Morocco: a report on three Arabian countries. ICAR Technical Series, No. 11.

Hammadi, M., T. Khorchani, G. Khaldi, A. Majdoub, H. Abdouli and N. Slimane et al. (2001). Effect of diet supplementation on growth and reproduction in camels under arid range conditions. Biotechnology Agronomy Society Environment, 5: 69-72.

Iqbal, A., R.A. Gill, B.B. Khan, M. Younas and A.W. Jasra (1999). Comparative growth performance of young camelskept under station and farmers' conditions. Proceedings of the International Workshop on the Camel Calf. 24-26 October, Quarzate, Morocco, p. $198-200$.

Ismail, M.D. (1996). The dromedary camel as multipurpose animal. International Workshop on Sustainable Use of Rangelands and Desertification Control, 3-6 November, Jeddah, Saudi Arabia, p. $1-14$.

Jeanplong, F., M. Sharma, W.G. Somers, J.J. Bass and R. Kambadur (2001). Genomic organization and neonatal expression of the bovine myostatin gene. Mol. Cell Biochem., 220 (1-2): 31-37.

Kambadur, R., M. Sharma, T.P.L. Smith and J.J. Bass (1997). Mutations in myostatin (GDF8) in Double-Muscled Belgian Blue and Piedmontese Cattle. Genome Res., 7: 910-915. 
Kamoun, M. (1995). Dromedary meat: production, qualitative aspects and acceptability for transformation. Option Mediterraneennes Serie B, Etudes et Recherches, 13: 105-130.

Ko, C.F, T.T. Chiou, T.T. Chen, J.L. Wu, J.C. Chen and J.K. Lu (2007). Molecular cloning of myostatin gene and characterization of tissuespecific and developmental stage-specific expression of the gene in orange Spotted Grouper, Epinephelus coioides. Mar. Biotechnol., 9 (1): 20-32.

Liangyi, X., Q. Kaixian, Q. Hongqin, L. Lu, Y. Qiaoyi and L. Ingyun (2006). Molecular cloning and characterization of the myostatin gene in croceine croaker, Pseudosciaen acrocea. Mol. Biol. Reprod., 33: 129-136.

McPherron, A. C. and S.J. Lee (1997). Double muscling in cattle due to mutations in the myostatin gene. J. Proc. Natl. Acad. Sci., 94 (23): 12457-12461.

Muzzachi, S., A. Oulmouden, Y. Cherifi, H. Yahyaoui, M.A. Zayed, P. Burger, G.M. Lacalandra, B. Faye and E. Ciani (2015). Sequence and polymorphism analysis of the camel (Camelus dromedarius) myostatin gene. Emir. J. Food Agric., 27 (4): 367-373.

Ouda, J.O. (1995). Camel calf survival and performance under varying amounts of milk intake. Camel Newsletter, 11: 42-45.

Sahani, M.S., U.K. Bissa and N.D. Khanna (1998). Factors influencing pre and post weaning body weights and daily weight gain in indigenous breeds of camels under farm conditions. Proceedings of the Third Annual Meeting for Animal Production under Arid Conditions, United Arab Emirates University, 1: $59 \mathrm{pp}$.

Shah, M.G., S. Qureshia, M. Reissmann and J. Schwartzh (2006). Sequencing and sequence analysis of myostatin gene in the exon 1 of the camel (Camelus dromedarius). Pakistan Vet. J., 26 (4): 176178.

SPSS (2012). In "Statistical Package for Social Science". Release 11.5, SPSS INC, Chicago. USA. 


\section{تتابع جين الميوستاتين وإرتباطه بأداء النمو في سلالة الإبل المغربي}

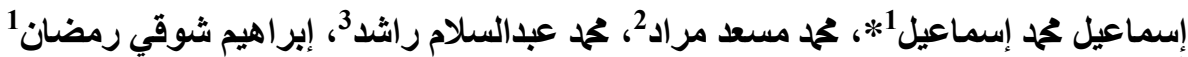

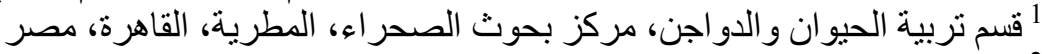

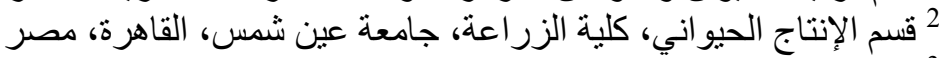

3 قسم الور اثثة، كلية الزر الزية الزي، جامعة عين شمس، القاهرة، مصر

إستخدم فى هذه الدراسة عدد 11 أم، 12 من المواليد (7 ذكور، 5 أناث) من سلالة الإبل

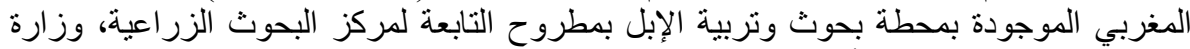

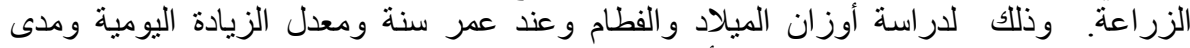

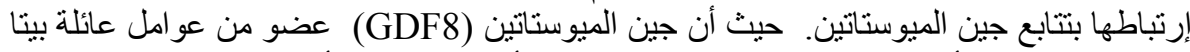

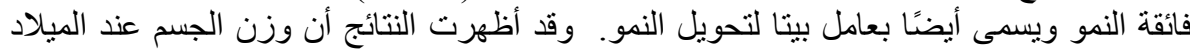

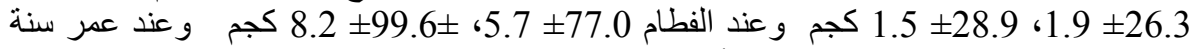

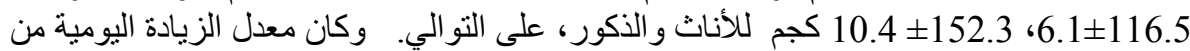

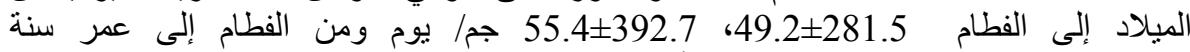

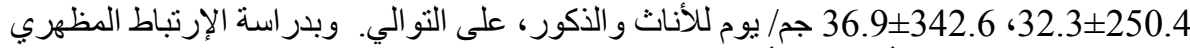
بين هذة الصفات وجد أن هناك أرتباط معنوي بين صفة وزن ألفطام والوزن عند عمر سنة

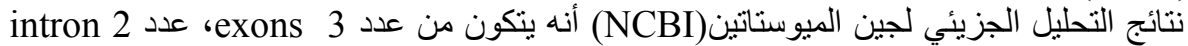

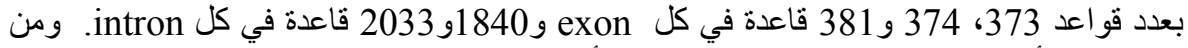

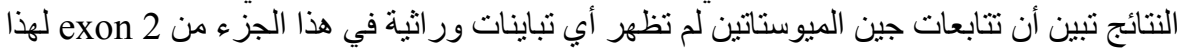

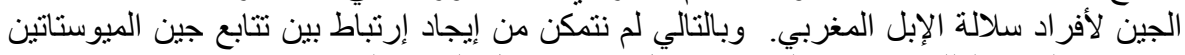

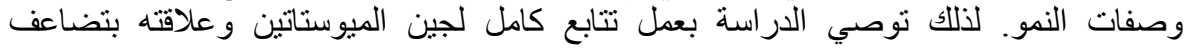
العضلات لإستخدامها في برامج التحسين الور اثي في الإبل المغربي. 